\title{
TRAUMATIC ATLANTOAXIAL SUBLUXATION, POSTERIOR TRANSFACET FIXATION: A CASE REPORT
}

\author{
SUBLUXAÇÃO ATLANTOAXIAL TRAUMÁTICA, FIXAÇÃO TRANSFACETÁRIA POSTERIOR: RELATO DE CASO \\ SUBLUXACIÓN ATLANTO-AXOIDEA POSTRAUMÁTICA, FIJACIÓN TRANSFACETARIA POSTERIOR: REPORTE DE CASO
}

Mario Cahueque Lemus' ${ }^{1}$, Enrique Vargas Uribe ${ }^{1}$, José María Jiménez Avila ${ }^{1}$

\begin{abstract}
Cervical spine injuries are often described as catastrophic events in neurological terms, with very low survival rate. Lesions to C3-C7 segment are the most common (about 80\%) followed by segment C1-C2 (20\%). The cervical spine injuries are of great importance, both by severity as the neurological implications. It is important to consider that among cervical traumas that do not present neurological damage at the time of the accident, $10 \%$ have deficits later, so all cervical trauma should be considered as potential spinal cord traumas, until the evolution of the case shows that definitively there is no spinal cord or nerve root damage. Cases have been reported with both atlantooccipital and atlantoaxial dislocations without neurological deficit, so these lesions went unnoticed in the emergency services. Some of the events to be considered at the time of the accident are suboccipital pain on axial skull pressure and spontaneous stiffness of the patient's neck. Dysphagia, pain on palpation of the anterior neck and a visible increase of prepharyngeal mass can also be observed, which is why it is important to keep the suspicion of craniocervical trauma in all patients who have these symptoms and carry out the relevant tests. This paper presents a case of post-traumatic atlantoaxial dislocation, which showed no neurological deficit at the time of the accident, but was later presented, as well as the surgical procedure carried out.
\end{abstract}

Keywords: Atlantoaxial joint; Joint instability; Dislocation.

\section{RESUMO}

As lesões da coluna cervical são frequentemente descritas como eventos catastróficos em termos neurológicos, com sobrevida curta. As lesões do segmento C3-C7 são as mais comuns (cerca de 80\%), seguidas pelo segmento C1-C2 (20\%). As lesões da coluna cervical são de grande importância, tanto pela gravidade quanto pelas implicações neurológicas que acarretam. É importante considerar que dos traumas cervicais que não apresentam danos neurológicos no momento do acidente, $10 \%$ apresentam déficits mais tarde, motivo pelo qual todos os traumas cervicais devem ser considerados possíveis traumas raquimedulares, até que a evolução do caso demonstre que definitivamente não há lesão medular ou radicular. Foram relatados casos de luxações atlanto-occipitais e atlantoaxiais sem déficit neurológico, portanto, essas lesões passam despercebidas nos serviços de emergência. Algumas das manifestações a serem consideradas no momento do acidente são dor suboccipital à pressão axial do crânio e rigidez espontânea do pescoço do paciente. Também podem ser obsenvados disfagia, dor à palpação da parte anterior do pescoço e aumento de volume pré-faríngeo visível, motivo pelo qual é importante manter a suspeita de traumatismo craniocervical em todos os pacientes que têm esses sintomas, e realizar os exames pertinentes. Neste artigo é apresentado um caso de luxação atlantoaxial pós-traumática, que não apresentou déficit neurológico no momento do acidente, que sobreveio posteriormente, assim como o tratamento cirúrgico realizado.

Descritores: Articulação atlantoaxial; Instabilidade articular; Luxação.

\section{RESUMEN}

Las lesiones de la columna cervical se describen comúnmente como eventos neurológicamente catastróficos con una tasa de supervivencia muy baja. Las lesiones del segmento C3-C7 son las más frecuentes (alrededor del 80\%) seguidas por el segmento C1-C2 (20\%). Las lesiones de la columna cervical son de gran importancia, tanto por su gravedad así como por las implicaciones neurológicas que conllevan. Es importante tener en cuenta que de los traumatismos cervicales que no presentan daño neurológico en el momento inmediato del accidente, un $10 \%$ lo presentaran con posterioridad, por lo que todos los traumatismos cervicales se deben considerar como potenciales traumas raquimedulares, hasta que la evolución a posterior demuestre que no hay daño medular o radicular en forma definitiva. Se ha reportado casos con presentación sin déficit neurológico tanto en dislocaciones atlanto-occipitales como atlanto-axoideas, por lo que estas lesiones pasan desapercibidas en el servicio de urgencias. Algunas de sus manifestaciones a tener en consideración en el momento del accidente son, dolor suboccipital a la presión axial del cráneo y cuello rígido espontáneo del paciente. También puede presentarse disfagia, dolor a la palpación de la parte anterior del cuello y aumento de volumen prefaringeo visible, por lo que es importante mantener la sospecha ante todo paciente con trauma cráneo cervical quien presenta estos síntomas y realizar los exámenes pertinentes. En este artículo se presenta un caso de luxación atlanto-axoidea postraumática que no presentaba déficit neurológico en el momento del accidente pero posteriormente se desarrollo, así como el manejo quirúrgico realizado.

Descriptores: Articulación atlanto-axoidea; Inestabilidad de la articulación; Luxaciones.

\section{INTRODUCTION}

Craniocervical trauma is considered life threatening, due to the devastating neurological damage it causes. Thanks to advances in modern medical systems and the care of patients with trauma, the number of patients who survive these injuries has increased. Universal precautions in the care of the vertebral spine, and bet- ter stabilization of the vertebral spine at the moment of transfer to a specialized center, have led to a better outcome., ${ }^{1,2}$ Cervical, occipitocervical, and $\mathrm{C} 1 / \mathrm{C} 2$ injuries and their evolution present a confused clinical manifestation that can lead to diagnostic error. These confounding variables include: multiple associated injuries, lack of appropriate imaging studies, and low clinical suspicion due

1. Hospital de Especialidades, Centro Médico Nacional de Occidente. Instituto Mexicano del Seguro Social. Guadalajara, Jalisco, Mexico.

Study conducted th the Spine Clinic. Afternoon Shift. Hospital de Especialidades, Centro Médico, Nacional de Occidente. IMSS. Guadalajara, Jalisco, Mexico.

Correspondence: Belisario Dominguez No 1000, Colonia Independencia, Guadalajara Jalisco. C.P. 44340. Jefatura Traumatología y Ortopedia. mariocahueque@gmail.com 
to a lack of specific symptoms. ${ }^{1,3-5}$ Injuries in $30 \%$ of cases may be combined, atlantoaxial and occipitocervical, with high mortality rates. ${ }^{1}$ There are reports of patients with cervical injury without neurological deficit, in which delayed diagnosis and initial stabilization lead to a worse prognosis for the patient in the short to medium terms. Once the diagnosis of cervical injury, specifically atlantoaxial, has been established, reduction and early fusion are recommended as definitive treatment, to prevent the development of neurological disturbances, which may be irreversible, even placing the patient's life at risk. Although there are currently various techniques for the treatment of these injuries, the results depend on the surgical technique that the specialist spinal surgeon is familiar with. .,3,6,7 $^{2}$

\section{Clinical case}

General information: Male patient aged 28 years, born and residing in Guadalajara, Jalisco, a Roman Catholic, educated to high school level, working as a carpenter. Inherited diseases: Denied by the patient. Disease history: Denies chronic-degenerative diseases. No previous surgery.

Patient reports that two months previously (August 2012), prior to admission, he suffered a physical assault causing cranioencephalic and cervical trauma. He was assessed at the Hospital General de Zona, where he was diagnosed with mild cervical sprain. The patient was discharged at the same time, without neurological deficit. The patient reports that after discharge, he began to experience paresthesia of the upper limbs with intermittent onset, followed by a gradual decrease in muscle strength, prompting him to come to this center for assessment.

Patient is conscious and oriented as to time, space and person. The neurological exam presents hypoesthesia of the upper limbs, with a decrease in muscle strength, 4/5 (Daniels scale). Patient has pain on moving the neck and pain on axial compression. Denies dysphagia.

Imaging studies were performed (Figure 1) which showed, in CT image reconstruction, loss of atlantoaxial joint congruence. Figure 2 shows the lateral Radiography and the measurement of $\mathrm{C} 1 / \mathrm{C} 2$, the ADI interval, and the Powers index.

The atlantoaxial region is marked and the dissection extends laterally until the atlantoaxial joints on both sides were visualized, as well as the joint facets. The facets of the atlas and axis were visualized directly, and distraction was performed manually, using a cranialhalo, achieving adequate alignment. Transfacet posterior instrumentation of $\mathrm{C} 1 / \mathrm{C} 2$ was performed, (Figure 3) without using large screws, and it was seen in the radiography that the screws achieved adequate reduction. (Figure 3)

The normal anatomy between $\mathrm{C} 1$ and the odontoid apophysis is restored, as can be seen in the postsurgical control. (Figure 4)

Patient one year after surgery, with adequate evolution and without neurological deficit, stiffness, or pain on movement. (Figures 5 and 6)
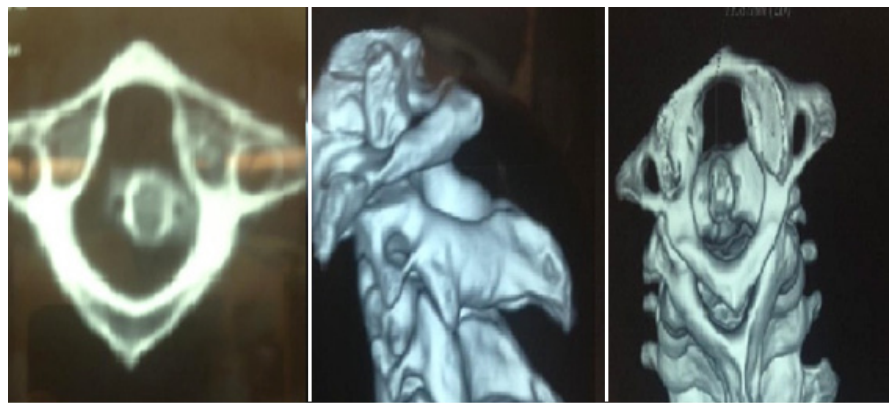

Figure 1. CT image reconstruction, atlantoaxial joint incongruences

\section{DISCUSSION}

Rotational lesions of the atlantoaxial joint were described for the first time by Corner, in 1907. These lesions are the result of flexion and rotation, with rupture of the transverse ligament. ${ }^{1,2,8}$

$\mathrm{C} 1-\mathrm{C} 2$ luxations are rare in adults, occurring in $<1 \%$ of all spinal

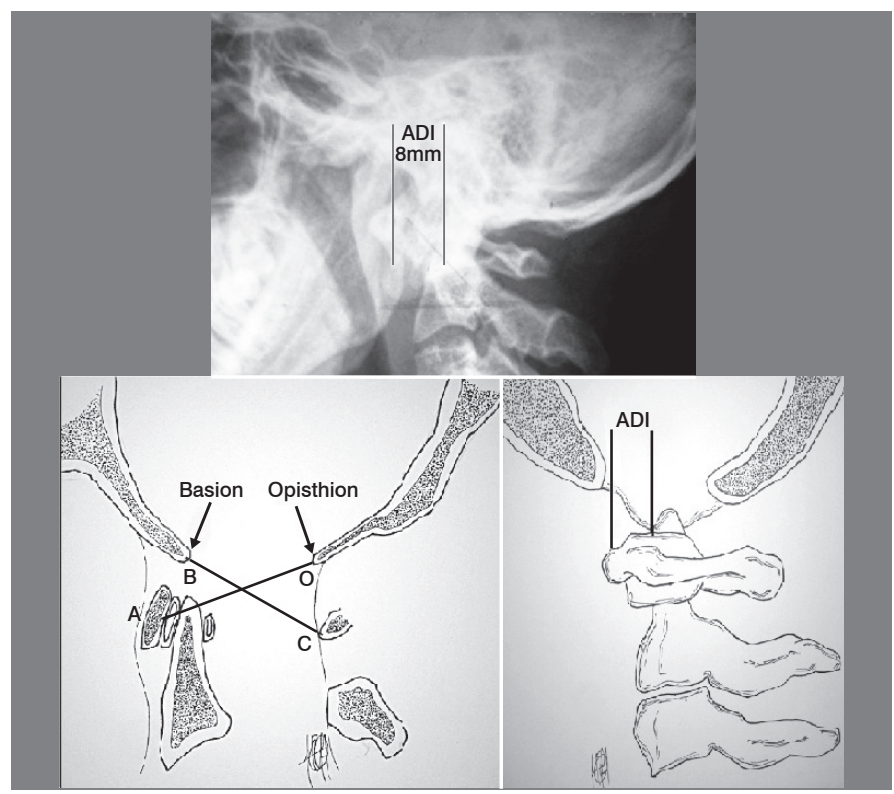

Figure 2. Lateral radiograph and measurement (ADI interval and Powers index).

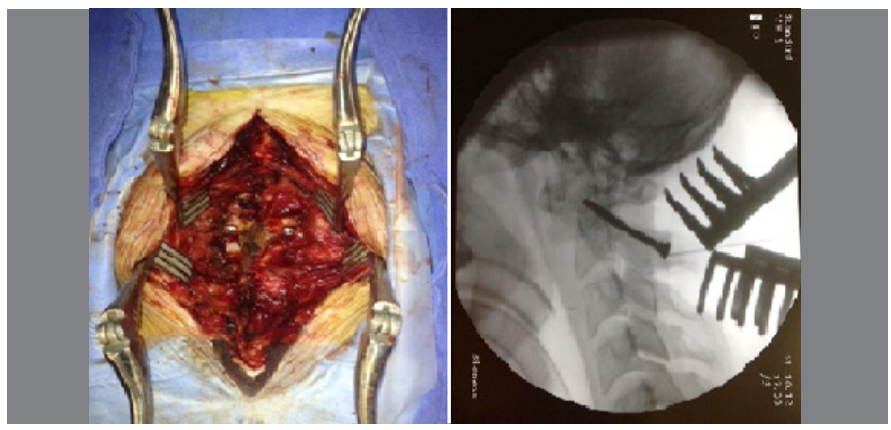

Figure 3. Postsurgical evolution.
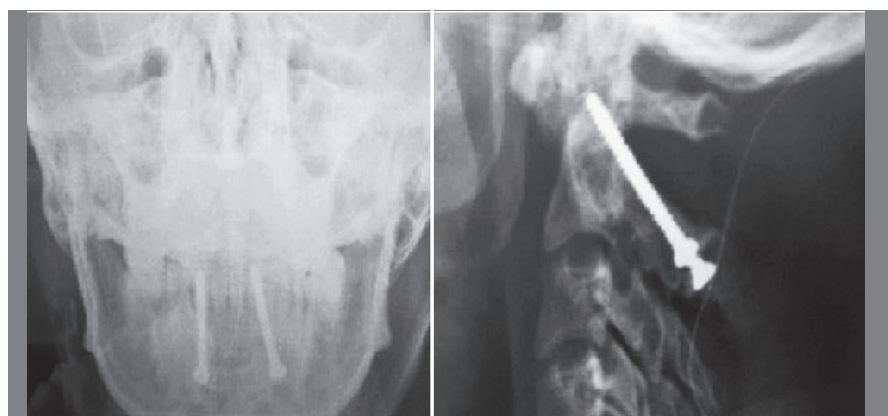

Figure 4. Postsurgical control.

injuries and around $20 \%$ of lesions of the cervical spine. . $^{1,3,9,10}$

Atlantoaxial subluxation is rare, and even more so without fracture of the dens (odontoid process) of the axis. As a result, it can sometimes be overlooked.

The intrinsic stability of the atlantoaxial complex is provided by the dens apophysis, which binds to the ventral osteoligamentous ring, formed by the anterior arch of the atlas, and dorsally by the transverse ligament. $2,6,11$

The transverse ligament and facet joint capsule impede the anterior translation of $\mathrm{C} 1$ on $\mathrm{C} 2$. The alar ligaments connect to the posterolateral apex of the dens with the lateral aspect of the magnum foramen bilaterally, which limits particularly anterior displacement of the atlas in the dens and excessive rotation of $\mathrm{C} 1$ on $\mathrm{C} 2 .{ }^{12}$ The pattern of injury is consistent with a mechanism of high-degree hyperextension. ${ }^{4}$

The diagnosis is generally difficult; the clinical manifestations are usually rare, such as suboccipital pain on axial pressure on the skull, 


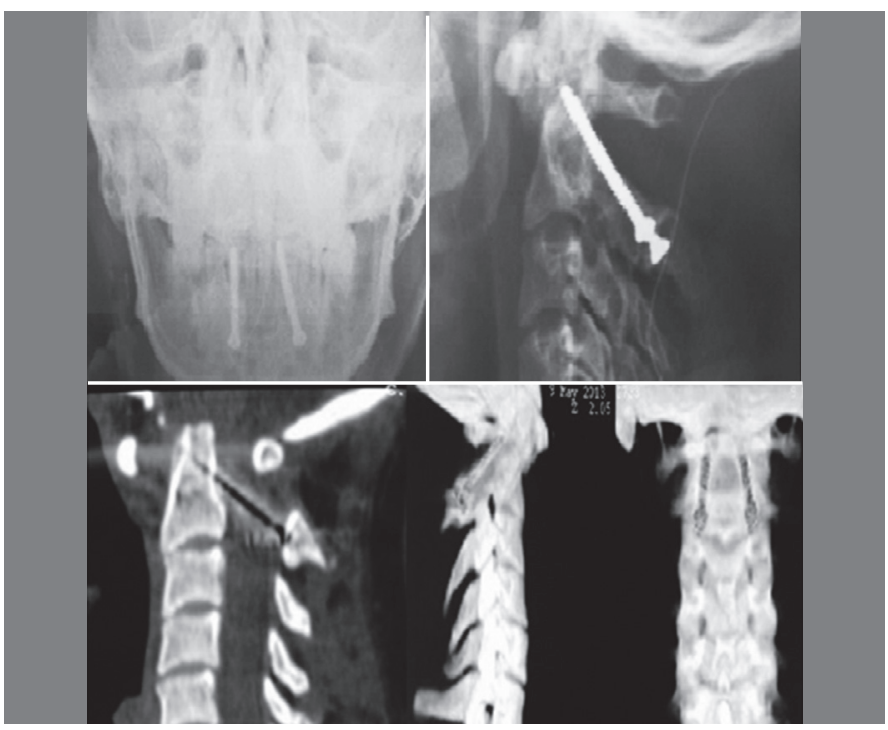

Figures 5 and $\mathbf{6}$. Evolution 1 year after surgery.

and on moving the skull the patient spontaneously stiffens the neck, contracting the sternocleidomastoid and trapezius muscles, with dysphagia and pain on anterior palpation of the neck $^{3,8}$, torticollis, and occipital neuralgia. Symptoms of vertebrobasilar insufficiency may sometimes be present. Where there is suspicion, imaging studies, plain AP and lateral radiography should be carried out, with their respective measurements, and even more importantly, computed axial tomography with $3 \mathrm{D}$ reconstruction. . $^{1,3-5,9,13}$

Early diagnosis is essential, as a longer period between the lesion and its reduction is correlated with higher rates of recurrence and failure of the reduction through non-surgical techniques ${ }^{14} \mathrm{We}$ believe that simple radiographic measurements (ADI and Powers Index) of the cervical spine can help in the interpretation of anomalies in segment $\mathrm{C} 1 / \mathrm{C} 2$, as in this case, where both measurements showed values compatible with $\mathrm{C} 1 / \mathrm{C} 2$ disassociation, as well as helping the team of the emergency unit avoid overlooking these potentially devastating entities.

The craniocervical joint is an anatomically complex functional structure that represents the transition zone between the skull and the spinal cord, enabling extension, flexion and lateral rotation of the head. In particular, the atlantoaxial segment has unique characteristics compared with the lower cervical portion, due to its ample range of rotation. ${ }^{1,2}$

There are magnetic resonance imaging tests that suggest that interruption of the alar ligament is the mechanism by which a rotatory subluxation is produced. ${ }^{15,16}$ The alar ligaments are the main structures responsible for the stability of rotation, as they limit the rotation to $45^{\circ} .5,14$

Fielding and Hawkins ${ }^{10}$ describe 4 types of atlantoaxial rotation with rotation of the transversal ligament. (Table 1) Our patient is

\section{REFERENCES}

1. Bisson E, Schiffern A, Daubs MD, Brodke DS, Patel AA. Combined occipital-cervical and atlantoaxial disassociation without neurologic injury: case report and review of the literature. Spine (Phila Pa 1976). 2010;35(8):E316-21.

2. Maida G, Marcati E, Sarubbo S. Posttraumatic atlantoaxial rotatory dislocation in a healthy adult patient: a case report and review of the literature. Case Rep Orthop. 2012;2012:183581. 3. Pissonnier ML, Lazennec JY, Renoux J, Rousseau MA. Trauma of the upper cervical spine: focus on vertical atlantoaxial dislocation. Eur Spine J. 2013:22(10):2167-75.

4. Chaudhary R, Chaudhary K, Metkar U, Rathod A, Raut A, Sanghvi D. Posterior atlantoaxial dislocation without odontoid fracture. Skeletal Radiol. 2008;37(4):361-6.

5. Neumann U, Urbanski H, Riedel K. Posterior atlantoaxial dislocation without fracture of the odontoid. A case report. J Bone Joint Surg Am. 2003;85(7):1343-6.

6. Kim YS, Lee JK, Moon SJ, Kim SH. Post-traumatic atlantoaxial rotatory fixation in an adult: a case report. Spine (Phila Pa 1976). 2007;32(23):E682-7.

7. Lapsiwala SB, Anderson PA, Oza A, Resnick DK. Biomechanical comparison of four C1 to $\mathrm{C} 2$ rigid fixative techniques: anterior transarticular, posterior transarticular, $\mathrm{C} 1$ to $\mathrm{C} 2$ pedicle, and C1 to C2 intralaminar screws. Neurosurgery. 2006:58(3):516-21

8. Abumi K, Takada T, Shono Y, Kaneda K, Fujiya M. Posterior occipitocervical reconstruction using cervical pedicle screws and plate-rod systems. Spine (Phila Pa 1976). 1999;24(14):1425-34
Table 1. Classification of Atlantoaxoid Luxation by Fielding and Hawkins. ${ }^{6}$

\begin{tabular}{c|c|c}
\hline Type & Transverse Ligament & Atlantodental interval \\
\hline Type I & None & $<3 \mathrm{~mm}$ \\
\hline Type II & $\begin{array}{c}\text { Defight } \\
\text { and Alar ligaments }\end{array}$ & $>5 \mathrm{~mm}$ \\
\hline Type III & $\begin{array}{c}\text { Deficiency of the Transverse } \\
\text { and Alar Ligaments }\end{array}$ & $\begin{array}{c}\text { Posterior change } \\
\text { of the Atlas }\end{array}$ \\
\hline Type IV
\end{tabular}

Adapted by: Kim YS, Lee JK, Moon SJ, Kim SH. Post-traumatic atlantoaxial rotatory fixation in an adult: a case report. Spine (Phila Pa 1976). 2007;32(23):E682-7.

classified as having a type IV lesion, in which the atlas can dislocate bilaterally forwards or backwards, with concomitant narrowing of the vertebral canal.

Dislocation in $\mathrm{C} 1-\mathrm{C} 2$ is a dynamic process that is generally irreducible and cannot be reduced by cervical traction. The treatment of this type of chronic and reducible dislocation is a challenge for surgeons, although improvements in surgical techniques have brought some encouraging results over the years. The main procedures reported in the literature are posterior occipitocervical/C1-C2 fusion and instrumentation, and transoral odontoidectomy. Recent improvements in the emergency diagnosis and therapeutic management have shown a higher rate of patient survival.

Fielding and Hawkins ${ }^{10}$ describe 4 types of atlantoaxial luxation with rupture of the transverse ligament; (Table 1) this case presented a type IV lesion, therefore it was decided on reduction with transfacet screws of $\mathrm{C} 2$ to $\mathrm{C} 1$, that even without using longer screws, has achieved adequate reduction, and good results after one year of follow-up. In these cases, occipitocervical fusion is generally considered as a form of neuroprotection, and should be performed as soon as possible. 1,5,7

Although there have been few published cases, the treatment by this type of pathology is fixation with transfacet screws, a technique that provides stability and adequate anatomical reduction. $1,5-7,9,10,15$

\section{FINAL CONSIDERATIONS}

The diagnosis of posttraumatic atlantoaxial luxation should be suspected in the presence of sprain and neck pain. However, atlantoaxial luxation can occur in the absence of any clinical symptoms, therefore this diagnosis should be systematically considered and ruled out in any patient with multiple traumas. The radiographic findings of the cervical spine, in AP and lateral views, can hinder the interpretation of luxation $\mathrm{C} 1 / \mathrm{C} 2$, therefore the routine use of CT scan of the cervical spine should be considered in all patients with cervical cranial trauma. When instability of the C1/C2 joint is diagnosed, timely reduction and fusion is recommended as definitive treatment.

All authors declare no potential conflict of interest concerning this article.

9. Moreau PE, Nguyen V, Atallah A, Kassab G, Thiong'o MW, Laporte C. Traumatic atlantoaxial dislocation with odontoid fracture: A case report. Orthop Traumatol Surg Res. 2012 Sep:98(5):613-7.

10. Fielding JW, Hawkins RJ. Atlanto-axial rotatory fixation. (Fixed rotatorysubluxation of the atlanto-axial joint). J Bone Joint Surg Am. 1977;59(1):37-44.

11. Ni B, Zhou F, Xie N, Guo X, Yang L, Guo Q, et al. Transarticular screw and C1 hook fixation for os odontoideum with atlantoaxial dislocation. World Neurosurg. 2011:75(3-4):540-6.

12. Wortzman G, Dewar FP. Rotary fixation of the atlantoaxial joint: Rotational atlantoaxial subluxation. Radiology. 1968;90(3):479-87.

13. Zhen $P$, Lan $X$, Yang LW. Traumatic posterior atlantoaxial dislocation without associated fracture and neurological deficit. Arch Orthop Trauma Surg. 2011:131(5):681-5.

14. Subach $B R$, McLaughlin MR, Albright AL, Pollack IF. Current management of pediatric atlantoaxial rotatory subluxation. Spine (Phila Pa 1976). 1998;23(20):2174-9

15. Willauschus WG, Kladny B, Beyer WF, Glückert K, Arnold H, Scheithauer R. Lesions of the alar ligaments. In vivo and in vitro studies with magnetic resonance imaging. Spine (Phila Pa 1976). 1995;20(23):2493-8.

16. Pratt $H$, Davies E, King L. Traumatic injuries of the $c 1 / c 2$ complex: computed tomographic imaging appearances. Curr Probl Diagn Radiol. 2008;37(1):26-38. 